\title{
Evaluation of Perceived Pain During the First Week of Rapid Maxillary Expansion Treatment
}

\author{
Hızlı Maksiller Genişletme Tedavisinin Illk Haftasında Hissedilen \\ Ağrının Değerlendirilmesi \\ (D) Mine Geçgelen Cesur ${ }^{1}$, (D) Alev Aksoy ${ }^{2}$
}

${ }^{1}$ Adnan Menderes University Faculty of Dentistry, Department of Orthodontics, Aydın, Turkey

${ }^{2}$ Süleyman Demirel University Faculty of Dentistry, Department of Orthodontics, Isparta, Turkey

Keywords

Rapid maxillary expansion, pain, orthodontic appliance

Anahtar Kelimeler

Hızlı maksiller ekspansiyon, ağrı, ortodontik aparey

Received/Geliş Tarihi : 29.03.2017

Accepted/Kabul Tarihi : 16.06.2017

doi:10.4274/meandros.02411

Address for Correspondence/Yazışma Adresi: Mine Geçgelen Cesur MD,

Adnan Menderes University Faculty of

Dentistry, Department of Orthodontics, Aydın, Turkey

Phone : +90 5447490199

E-mail : minegecgelen@hotmail.com

ORCID ID: orcid.org/0000-0002-4234-3496

(C) Meandros Medical and Dental Journal, Published by Galenos Publishing House.

This is article distributed under the terms of the

Creative Commons Attribution NonCommercial 4.0

International Licence (CC BY-NC 4.0).

\begin{abstract}
Objective: The aims of this study were to investigate the time at which pain started, the duration and intensity of the pain, the teeth affected in the mouth and whether sex was important in the perception of pain during the first week of rapid maxillary expansion (RME) treatment.

Materials and Methods: Sixty-two patients, 30 boys (mean age $12.91 \pm 0.70$ years), 32 girls (mean age 13.16 \pm 0.52 ) undergoing RME treatment with an acrylic-bonded appliance was surveyed. The appliance was activated with two turns per day. The patient's pain response was measured for each day in the morning and evening for a week using the Facial Pain Scale-Revised.

Results: Pain was reported by 66.12 per cent of patients after first activation of expansion appliance. No sex difference was found for percentage of patients reporting pain. At the posterior teeth, there were statistically significant results between the mean pain scores on days 2 and 6 in the morning and on days 1 and 6 in the evening for male patients.

Conclusion: Most of the patients undergoing RME treatment perceived pain, especially during the early phase of expansion. The maximum levels of pain were perceived during the first 5 days and showed variability among patients.
\end{abstract}

Öz

Amaç: Bu çalışmanın amacı hızlı maksiller genişletme (HMG) tedavisinin ilk haftasında ağrının başladığı zamanı, ağrının süresi ve yoğunluğunu, ağızda etkilenen dişleri ve cinsiyetin ağrı algısındaki önemini araştırmaktır.

Gereç ve Yöntemler: Akrilik bonded aparey ile HMG tedavisi uygulanan 30

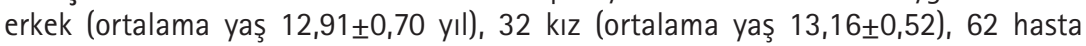
araştırmada yer almıştır. Aparey günde iki tur aktive edilmiştir. Hastanın ağrı yanıtı Yüz Ağrı Skalası-Revize versiyonu kullanılarak bir hafta boyunca her gün sabah ve akşam ölçülmüştür.

Bulgular: Genişletme apareyinin ilk aktivasyonundan sonra hastaların \%66,12'si tarafından ağrı rapor edilmiştir. Cinsiyetler arasında ağrı bildiren hastaların yüzdeleri bakımından herhangi bir fark bulunamamıştır. Arka dişlerde, sabah 2. ve 6. günlerde, akşam 1. ve 6. günlerde ortalama ağrı skorları arasında erkek hastalarda istatistiksel olarak anlamlı sonuçlar vardır.

Sonuç: HMG tedavisi gören hastaların çoğu, özellikle genişletmenin erken evresinde ağrı hissetmiştir. Maksimum ağrı seviyeleri ilk 5 gün boyunca algılanmış ve hastalar arasında değişkenlik göstermiştir. 


\section{Introduction}

Rapid maxillary expansion (RME) is used to correct transverse discrepancies between the maxilla and mandible by opening the mid-palatal suture $(1,2)$. This treatment is commonly preferred by many orthodontists in the primary, mixed or permanent dentition $(3,4)$.

Ten Cate et al. (5) reported traumatic tears, death of fibroblasts, disruption of collagen fibres, and acute inflammation after exerting an expansion force in rats. As part of this inflammatory process, the patient feels a painful sensation, which is often expressed in the whole craniofacial region (6).

Orthodontic pain and discomfort may negatively affect patient cooperation and discourage some patients from seeking treatment $(7,8)$. Different studies have shown that $70-95 \%$ of patients complain of the pain caused by orthodontic appliances (9-11).

In the literature, many studies have reported pain associated with different orthodontic procedures such as placement of separator, miniplate, microimplant, archwire, wear of elastics, headgear and debonding (12-18). Few studies have explored the pain and the discomfort during RME treatment $(1-3,19)$.

The purpose of this study was to investigate the following questions after application of RME appliance: (1) the time at which the pain started, (2) the duration and intensity of the pain, (3) the teeth affected in the mouth and (4) whether sex was important in the perception of pain.

\section{Materials and Methods}

The study group was comprised of a total of 62 patients ( 30 boys, 32 girls) who applied to Department of Orthodontics at Adnan Menderes University for orthodontic treatment. The mean age was $12.91 \pm 0.70$ years for boys and $13.16 \pm 0.52$ years for girls. The inclusion criteria were functional unilateral or bilateral posterior crossbite with transverse deficiency, the absence of any craniofacial anomalies such as cleft lip and palate. All patients were between S and MP3u maturation stages at the beginning of treatment. The patients were informed about the treatment procedures and informed consent was obtained from all patients. This study was approved by the Research Ethics Committee of the Süleyman Demirel University with the reference number 72867572-050-1186.
All patients were treated with an acrylic-bonded RME appliance as described by Akkaya et al. (20). The expansion screw was activated by the patients twice a day with one-quarter turn in the morning and in the evening until the palatal cusps of the maxillary first molars contacted the buccal cusps of the mandibular first molars. The questionnaires were analyzed by one of the authors, who were blinded to the study and performed no orthodontic treatment on the patients.

The patients were given prepared questionnaires and instructed on how they should be completed after the RME appliances were bonded. The first activation was performed in the dental clinic in the morning. The patient was asked to rate his/her perceived pain using pain scale immediately after the activation and repeat the expansion procedure and pain measurements at home for the remaining turns. The questionnaires were completed by all patients after one week. Question 1 is about the time at which pain first perceived after first activation of expansion screw. In the following questions, the patients were asked individually for each day in the morning and in the evening for a week, whether they felt pain, in which teeth they perceived pain. The Faces Pain Scale-Revised (FPS-R) was used for measurement of the intensity of the pain. It is comprised of six horizontally arranged sex-and race-neutral faces depicting expressions of "no pain" (furthest left) to "very much pain" (furthest right) on a piece of paper. The patient is asked to point to the face that indicates how much pain he/she feels, and his/her reported pain is subsequently scored $0,2,4,6,8,10$ for the six faces (Figure 1) (21).

\section{Statistical Analysis}

All analyses were performed with the software SPSS 18.0 for Windows (SPSS, Inc., Chicago, Illinois). Z-test analysis was used for comparison of the ratios between the sex and the percentage of patients reporting pain. FPS-R scores over the study period were assessed using Friedman rank test followed by Bonferroni-Dunn test to ascertain significance between the mean ranks of days. $P$ value $<0.05$ was considered statistically significant.

\section{Results}

Pain was reported by 66.12 per cent (41 patients) after first activation of expansion screw. 87.80 per cent (36 patients) perceived pain in the first two hours (Table 1). 
Comparison of the percentages of patients reporting pain according to sex showed that there were no statistically significant results $(p>0.05)$ (Table 2).

Distribution of patients reporting pain at the anterior and posterior teeth regions through 8 days were showed in Table 3. The percentage of patients reporting pain at the posterior teeth was greater than the anterior teeth.

Table 4 showed the distribution of mean FPS-R scores of each morning and evening according to

\begin{tabular}{|c|c|c|c|c|c|c|}
\hline \multicolumn{7}{|c|}{$\begin{array}{l}\text { Table } 1 \text {. Distribution of } \\
\text { first activation } \\
\qquad \text { Time of initial pain }\end{array}$} \\
\hline & \multicolumn{2}{|c|}{ The first 2 hours } & \multicolumn{2}{|c|}{ After the 2 nd hour } & \multicolumn{2}{|c|}{ Total } \\
\hline & $\mathbf{n}$ & $\%$ & $n$ & $\%$ & $n$ & $\%$ \\
\hline Pain & 36 & 87.80 & 5 & 12.19 & 41 & 100.00 \\
\hline \multicolumn{7}{|c|}{$\begin{array}{l}\text { \%: Percentage of patients reporting pain, } \mathrm{n} \text { : Number of patients } \\
\text { reporting pain }\end{array}$} \\
\hline
\end{tabular}

\begin{tabular}{|c|c|c|c|c|c|c|c|c|}
\hline \multirow{3}{*}{ Days } & \multicolumn{4}{|c|}{ Morning } & \multicolumn{4}{|c|}{ Evening } \\
\hline & \multicolumn{2}{|c|}{ Female } & \multicolumn{2}{|c|}{ Male } & \multicolumn{2}{|c|}{ Female } & \multicolumn{2}{|c|}{ Male } \\
\hline & $n$ & $\%$ & $n$ & $\%$ & $n$ & $\%$ & $n$ & $\%$ \\
\hline $1^{\text {st }}$ day & $\begin{array}{l}20 \\
8\end{array}$ & $\begin{array}{l}62.50 \\
38.09\end{array}$ & $\begin{array}{l}21 \\
3\end{array}$ & $\begin{array}{l}70.00 \\
30\end{array}$ & $\begin{array}{l}17 \\
10\end{array}$ & $\begin{array}{l}53.12 \\
47.61\end{array}$ & $\begin{array}{l}21 \\
3\end{array}$ & $\begin{array}{l}70.00 \\
30\end{array}$ \\
\hline $2^{\text {nd }}$ day & $\begin{array}{l}24 \\
5\end{array}$ & $\begin{array}{l}75.00 \\
23.80\end{array}$ & $\begin{array}{l}24 \\
2\end{array}$ & $\begin{array}{l}80.00 \\
20\end{array}$ & $\begin{array}{l}24 \\
5\end{array}$ & $\begin{array}{l}75.00 \\
23.80\end{array}$ & $\begin{array}{l}21 \\
3\end{array}$ & $\begin{array}{l}70.00 \\
30\end{array}$ \\
\hline $3^{\text {rd day }}$ & $\begin{array}{l}23 \\
6\end{array}$ & $\begin{array}{l}71.87 \\
28.57\end{array}$ & $\begin{array}{l}21 \\
3\end{array}$ & $\begin{array}{l}70.00 \\
30\end{array}$ & $\begin{array}{l}23 \\
6\end{array}$ & $\begin{array}{l}71.87 \\
8.57\end{array}$ & $\begin{array}{l}21 \\
3\end{array}$ & $\begin{array}{l}70.00 \\
30\end{array}$ \\
\hline $4^{\text {th }}$ day & $\begin{array}{l}24 \\
5\end{array}$ & $\begin{array}{l}75.00 \\
23.80\end{array}$ & $\begin{array}{l}18 \\
4\end{array}$ & $\begin{array}{l}60.00 \\
40\end{array}$ & $\begin{array}{l}23 \\
6\end{array}$ & $\begin{array}{l}71.87 \\
28.57\end{array}$ & $\begin{array}{l}15 \\
5\end{array}$ & $\begin{array}{l}50.00 \\
50\end{array}$ \\
\hline $5^{\text {th }}$ day & $\begin{array}{l}24 \\
5\end{array}$ & $\begin{array}{l}75.00 \\
23.80\end{array}$ & $\begin{array}{l}18 \\
4 \\
\end{array}$ & $\begin{array}{l}60.00 \\
40\end{array}$ & $\begin{array}{l}24 \\
5 \\
\end{array}$ & $\begin{array}{l}75.00 \\
23.80 \\
\end{array}$ & $\begin{array}{l}21 \\
3 \\
\end{array}$ & $\begin{array}{l}70.00 \\
30 \\
\end{array}$ \\
\hline $6^{\text {th }}$ day & $\begin{array}{l}20 \\
8 \\
\end{array}$ & $\begin{array}{l}62.50 \\
38.09 \\
\end{array}$ & $\begin{array}{l}18 \\
4 \\
\end{array}$ & $\begin{array}{l}60.00 \\
40\end{array}$ & $\begin{array}{l}23 \\
6 \\
\end{array}$ & $\begin{array}{l}71.87 \\
28.57 \\
\end{array}$ & $\begin{array}{l}15 \\
5 \\
\end{array}$ & $\begin{array}{l}50.00 \\
50\end{array}$ \\
\hline $7^{\text {th }}$ day & $\begin{array}{l}20 \\
8\end{array}$ & $\begin{array}{l}62.50 \\
38.09\end{array}$ & $\begin{array}{l}18 \\
4\end{array}$ & $\begin{array}{l}60.00 \\
40\end{array}$ & $\begin{array}{l}23 \\
6\end{array}$ & $\begin{array}{l}71.87 \\
28.57\end{array}$ & $\begin{array}{l}18 \\
4\end{array}$ & $\begin{array}{l}60.00 \\
40\end{array}$ \\
\hline
\end{tabular}

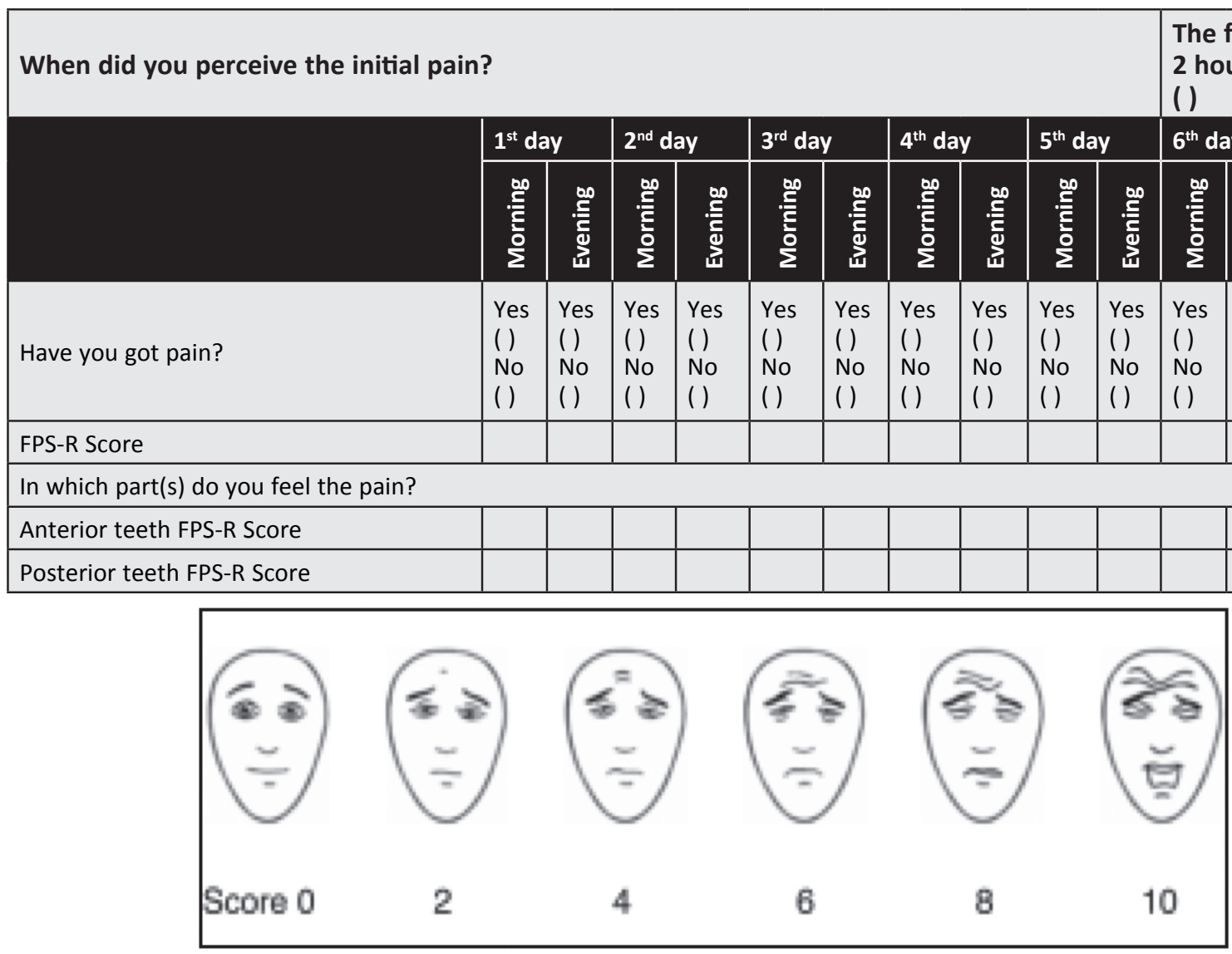

Figure 1. The questionnaire and faces pain scale-revised used in the study FPS-R: Facial Pain Scale-Revised 
sex. At the anterior teeth, there were no statistically significant results between the mean FPS-R scores regarding to each morning and evening for female and male subjects $(p>0.05)$. At the posterior teeth, there were statistically significant results between the mean FPS-R scores on days 2 and $6(p<0.05)$ in the morning and on days 1 and $6(p<0.05)$ in the evening for male patients (Table 4).

\begin{tabular}{|c|c|c|c|c|c|c|c|c|}
\hline \multirow{3}{*}{ Days } & \multicolumn{4}{|c|}{ Anterior teeth } & \multicolumn{4}{|c|}{ Posterior teeth } \\
\hline & \multicolumn{2}{|c|}{ Morning } & \multicolumn{2}{|c|}{ Evening } & \multicolumn{2}{|c|}{ Morning } & \multicolumn{2}{|c|}{ Evening } \\
\hline & $\mathbf{n}$ & $\%$ & $\mathbf{n}$ & $\%$ & n & $\%$ & $\mathbf{n}$ & $\%$ \\
\hline $1^{\text {st }}$ day & 16 & 25.80 & 12 & 19.35 & 32 & 53.54 & 34 & 54.83 \\
\hline $2^{\text {nd }}$ day & 20 & 32.25 & 24 & 38.70 & 42 & 67.74 & 38 & 61.29 \\
\hline $3^{\text {rd }}$ day & 22 & 35.48 & 24 & 38.70 & 38 & 61.29 & 40 & 64.51 \\
\hline $4^{\text {th }}$ day & 28 & 45.16 & 22 & 35.48 & 36 & 58.06 & 36 & 58.06 \\
\hline $5^{\text {th }}$ day & 26 & 41.93 & 20 & 32.25 & 34 & 54.83 & 36 & 58.06 \\
\hline $6^{\text {th }}$ day & 18 & 29.03 & 18 & 29.03 & 34 & 54.83 & 30 & 48.38 \\
\hline $7^{\text {th }}$ day & 18 & 29.03 & 20 & 32.25 & 28 & 45.16 & 30 & 48.38 \\
\hline \multicolumn{9}{|c|}{$\begin{array}{l}\% \text { : Percentage of patients reporting pain, } n \text { : Number of patients } \\
\text { reporting pain }\end{array}$} \\
\hline
\end{tabular}

\section{Discussion}

Pain is a complex emotion that alters from one individual to another; hence its objective evaluation is difficult. Multiple tools have been used for the measurement of pain intensity or severity (2). Studies have shown that children at 3 years of age and older are capable of understanding the concept of pain and its varying degrees of intensity, if provided with an appropriate device $(3,4)$. The FPS-R was used in the assessment of pain in this study. dos Santos Calderon et al. (22), Hembrecht et al. (23), Wong et al. (24) used FPS-R in their dental studies. It has the advantage of being suitable for use with the most widely used metric scale for scoring (0-10), and conforms closely to a linear interval scale (21).

Previous studies suggest that most patients undergoing this orthodontic procedure report pain, which generally occurs during the initial phase and diminishes thereafter (1-4,19). Therefore, we limited the duration of our study with one week. Twoactivations/day protocol was used, and pain was measured both in the morning and the evening.

Zimring and Isaacson (25) reported that the maximum load produced by any single activation occurs immediately at the time of turning of the jackscrew and begins to dissipate soon thereafter. In this study, most of the patients perceived pain within two hours after first activation.

In this study, the sex of the patient was not a significant factor in reporting pain during RME. This

\begin{tabular}{|c|c|c|c|c|c|c|c|c|}
\hline \multirow{4}{*}{ Days } & \multicolumn{8}{|c|}{ Mean FPS-R Scores } \\
\hline & \multicolumn{4}{|c|}{ Anterior teeth } & \multicolumn{4}{|c|}{ Posterior teeth } \\
\hline & \multicolumn{2}{|l|}{ Morning } & \multicolumn{2}{|l|}{ Evening } & \multicolumn{2}{|l|}{ Morning } & \multicolumn{2}{|l|}{ Evening } \\
\hline & Female & Male & Female & Male & Female & Male & Female & Male \\
\hline $1^{\text {st }}$ day & 4.14 & 4.20 & 4.02 & 4.00 & 4.71 & 5.50 & 4.50 & $5.85^{a^{*}}$ \\
\hline $2^{\text {nd }}$ day & 4.26 & 4.15 & 4.67 & 4.60 & 4.88 & $5.80^{a^{*}}$ & 4.93 & 5.05 \\
\hline $3^{\text {rd }}$ day & 5.17 & 5.30 & 4.67 & 4.70 & 5.40 & 4.45 & 5.19 & 4.85 \\
\hline $4^{\text {th }}$ day & 4.43 & 5.05 & 4.07 & 4.60 & 4.45 & 3.90 & 4.43 & 3.90 \\
\hline $5^{\text {th }}$ day & 4.60 & 4.10 & 4.48 & 4.70 & 4.76 & 4.30 & 4.83 & 4.30 \\
\hline $6^{\text {th }}$ day & 4.21 & 4.35 & 4.64 & 4.05 & 4.02 & $3.65^{b^{*}}$ & 4.52 & $3.65^{b^{*}}$ \\
\hline $7^{\text {th }}$ day & 4.62 & 3.90 & 4.98 & 4.45 & 3.98 & 4.35 & 3.95 & 3.95 \\
\hline
\end{tabular}


finding concurs with the other studies $(1,3,13,14)$. Hogeweg et al. (26) reported that mechanical pain thresholds were not different among boys and girls aged 6-17 years old.

Although the results were not statistically significant, the percentage of patients reporting pain at the posterior teeth was greater than at the anterior teeth. It is logical because the appliance was bonded to the posterior teeth and the expansion pattern during RME results in dentoalveolar expansion (also dental tipping) being larger than skeletal expansion. This finding is in accordance with the findings by Feldmann and Bazargani (1) and Bazargani et al. (27)

It is reported that most patients undergoing RME perceive pain, especially during the early phase of expansion. The maximum levels of pain were reported during the first 5 days with the greatest intensity during the first 3 days and a steadily decreasing amount of pain thereafter. The current results indicated significantly lower levels of pain at the posterior teeth on day 6 than on day 1 and 2 for males. We observed that this pain showed variability among patients. It has been stated that the pain reported by patients does not seem to be directly related to the magnitude of force exerted. It relies heavily on the psychological well being of the individual (28).

\section{Conclusion}

- Eighty seven percent of the patients perceived pain in the first two hours.

- No sex discrimination was found among the percentages of patients reporting pain.

- At the posterior teeth, there were statistically significant results between the pain levels on days 2 and 6 in the morning and on days 1 and 6 in the evening for male patients.

- The percentage of patients reporting pain at the posterior teeth was higher than at the anterior teeth.

Ethics

Ethics Committee Approval: This study was approved by the Research Ethics Committee of the Süleyman Demirel University with the reference number 72867572-050-1186.

Informed Consent: Informed consent was obtained from all patients.

Peer-review: Externally peer-reviewed.

\section{Authorship Contributions}

Surgical and Medical Practices: M.G.C., Concept: M.G.C., A.A., Design: M.G.C., A.A., Data Collection or Processing: M.G.C., A.A., Analysis or Interpretation: M.G.C., A.A., Literature Search: M.G.C., A.A., Writing: M.G.C.

Conflict of Interest: No conflict of interest was declared by the authors.

Financial Disclosure: The authors declared that this study received no financial support.

\section{References}

1. Feldmann I, Bazargani F. Pain and discomfort during the first week of rapid maxillary expansion (RME) using two different RME appliances: A randomized controlled trial. Angle Orthod 2017; 87: 391-6.

2. Gecgelen M, Aksoy A, Kirdemir P, Doguc DK, Cesur G, Koskan $O$, et al. Evaluation of stress and pain during rapid maxillary expansion treatments. J Oral Rehabil 2012; 39: 767-75.

3. Needleman HL, Hoang CD, Allred E, Hertzberg J, Berde C. Reports of pain by children undergoing rapid palatal expansion. Pediatr Dent 2000; 22: 221-6.

4. Baldini A, Nota A, Santariello C, Assi V, Ballanti F, Cozza P. Influence of activation protocol on perceived pain during rapid maxillary expansion. Angle Orthod 2015; 85: 1015-20.

5. Ten Cate AR, Freeman E, Dickónson JB. Sutural development: structure and its response to rapid expansion. Am J Orthod 1977; 71: 622-36.

6. Joviliano $P$, Junqueira AA, Stabile AC, Leite-Panissi CRA, Rocha MJA. Rapid maxillary expansion causes neuronal activation in brain structures of rats. Brain Res Bull 2008; 76: 396-401.

7. Oliver RG, Knapman YM. Attitudes to orthodontic treatment. $\mathrm{Br}$ J Orthod 1985; 12: 179-88.

8. Čirgić $\mathrm{E}, \mathrm{Kjell}$ berg $\mathrm{H}$, Hansen $\mathrm{K}$. Discomfort, expectations, and experiences during treatment of large overjet with Andresen Activator or Prefabricated Functional Appliance: a questionnaire survey. Acta Odontol Scand 2017; 2: 1-7.

9. Kvam E, Bondevik O, Gjerdet NR. Traumatic ulcers and pain during orthodontic treatment. Community Dent Oral Epidemiol 1989; 17: 154-7.

10. Scheurer P, Firestone A, Bürgin W. Perception of pain as a result of orthodontic treatment with fixed appliances. Eur J Orthod 1996; 18: 349-57.

11. Almallah MM, Almahdi WH, Hajeer MY. Evaluation of low level laser therapy on pain perception following orthodontic elastomeric separation: A randomized controlled trial. J Clin Diagn Res 2016; 10: ZC23-ZC28.

12. Tuncer Z, Ozsoy FS, Ozsoy OP. Self-reported pain associated with the use of intermaxillary elastics compared to pain experienced after initial archwire placement. Angle Orthod 2011; 81: 807-11.

13. Minor V, Marris CK, McGorray SP, Yezierski R, Fillingim R, Logan $\mathrm{H}$, et al. Effects of preoperative ibuprofen on pain after separator placement. Am J Orthod Dentofacial Orthop 2009; 136: 510-7. 
14. Erdinç AM, Dinçer B. Perception of pain during orthodontic treatment with fixed appliances. Eur J Orthod 2004; 26: 79-85.

15. Lee $\mathrm{T}$, McGrath $\mathrm{C}$, Wong R. Patients regarding microimplants as anchorage in orthodontics. Angle Orthod 2008; 78: 228-33.

16. Firestone AR, Scheurer PA, Bürgin WB. Patient's anticipation of pain and pain-related side effects, and their perception of pain as a result of orthodontic treatment with fixed appliances. Eur J Orthod 1999; 21: 387-96.

17. Rinchuse DJ. Pain-free debonding with occlusal rim wax. J Clin Orthod 1994; 28: 587-8.

18. Bavbek NC, Tuncer BB, Tortop T, Celik B. Efficacy of different methods to reduce pain during debonding of orthodontic brackets. Angle Orthod 2016; 86: 917-24.

19. Halicioğlu K, Kiki A, Yavuz I. Subjective symptoms of RME patients treated with three different screw activation protocols: a randomised clinical trial. Aust Orthod J 2012; 28: 225-31.

20. Akkaya S, Lorenzon S, Ucem TT. Comparison of dental arch and arch perimeter changes between bonded and slow maxillary expansion procedures. Eur J Orthod 1998; 20: 255-61.

21. Hicks CL, von Baeyer CL, Spafford P, van Korlaar I, Goodenough B. The Faces Pain Scale - Revised: Toward a common metric in pediatric pain measurement. Pain 2001; 93: 173-83.
22. dos Santos Calderon P, Peixoto RF, Gomes VM, da Mota Corrêa AS, de Alencar EN, Rossetti LM. Concordance among different pain scales in patients with dental pain. J Orofac Pain 2012; 26: 126-31.

23. Hembrecht EJ, Nieuwenhuizen J, Aartman IH, Krikken J, Veerkamp JS. Pain-related behaviour in children: a randomised study during two sequential dental visits. Eur Arch Paediatr Dent 2013; 14: 3-8.

24. Wong M, Copp PE, Haas DA. Postoperative pain in children after dentistry under general anesthesia. Anesth Prog 2015; 62: 14052.

25. Zimring JF, Isaacson RJ. Forces produced by rapid maxillary expansion. III. forces present during retention. Angle Orthod 1965; 35: 178-86.

26. Hogeweg JA, Kuis W, Oostendorp RA, Helders PJ. The influence of site of stimulation, age and gender on pain threshold in healthy children. Phys Ther 1996; 76: 1331-39.

27. Bazargani F, Feldmann I, Bondemark L. Three-dimensional analysis of effects of rapid maxillary expansion on facial sutures and bones. Angle Orthod 2013; 83: 1074-82.

28. Önçağ G, Dindaroğlu F, Doğan S. Perception of pain during rapid palatal expansion. Turk Ortodonti Derg 2011; 24: 111-22. 